Claire Bar ORCID iD: 0000-0003-1489-0211

\title{
Expanding the genetic and phenotypic relevance of KCNB1 variants in developmental and epileptic encephalopathies: 27 new patients and overview of the literature
}

Claire Bar ${ }^{1,2,3}$, Giulia Barcia, ${ }^{2,3,4}$, Mélanie Jennesson ${ }^{5}$, Gwenaël Le Guyader ${ }^{6,7}$, Amy Schneider $^{8}$, Cyril Mignot ${ }^{9,10}$, Gaetan Lesca ${ }^{11,12}$, Delphine Breuillard ${ }^{1}$, Martino Montomoli $^{13}$, Boris Keren ${ }^{10}$, Diane Doummar ${ }^{14}$, Thierry Billette de Villemeur ${ }^{14}$, Alexandra Afenjar ${ }^{15}$, Isabelle Marey $^{10}$, Marion Gerard $^{16}$, Hervé Isnard $^{17}$, Alice Poisson $^{18}$, Sophie Dupont ${ }^{9,19}$, Patrick Berquin ${ }^{20}$, Pierre Meyer $^{21,22}$, David Genevieve $^{23,24}$, Anne De Saint Martin ${ }^{25}$, Salima El Chehadeh ${ }^{26}$, Jamel Chelly ${ }^{26}$, Agnès Guët $^{27}$, Emmanuel Scalais ${ }^{28}$, Nathalie Dorison ${ }^{29}$, Candace T. Myers ${ }^{30}$, Heather C. Mefford $^{31}$, Katherine B. Howell ${ }^{32,33}$, Carla Marini ${ }^{13}$, Jeremy L. Freeman ${ }^{32,33}$, Anca Nica $^{34}$, Gaetano Terrone ${ }^{35}$, Tayeb Sekhara ${ }^{36}$, Anne-Sophie Lebre ${ }^{37}$, Sylvie Odent ${ }^{38,39}$, Lynette G. Sadleir ${ }^{40}$, Arnold Munnich ${ }^{3,4}$, Renzo Guerrini ${ }^{13}$, Ingrid E. Scheffer ${ }^{8,32,41}$, Edor Kabashi $^{2,3}$, Rima Nabbout ${ }^{1,2,3}$

\section{Affiliations:}

${ }^{1}$ Reference centre for rare epilepsies, Department of Pediatric Neurology, Hôpital Necker-Enfants Malades, Paris, France

${ }^{2}$ Laboratory of Translational Research for Neurological Disorders, INSERM UMR 1163, Imagine Institute, Paris, France

${ }^{3}$ Université Paris Descartes -Sorbonne Paris Cité, Imagine Institute, Paris, France

${ }^{4}$ Service de Génétique, Groupe Hospitalier Necker Enfants Malades, Assistance Publique -Hôpitaux de Paris, Paris, France

${ }^{5}$ Department of Pediatrics, American Memorial Hospital, Reims, France

${ }^{6}$ Service de Génétique, CHU de Poitiers, BP 577, 86021 Poitiers Cedex

This is the author manuscript accepted for publication and undergone full peer review but has not been through the copyediting, typesetting, pagination and proofreading process, which may lead to differences between this version and the Version of Record. Please cite this article as doi: 10.1002/humu.23915.

This article is protected by copyright. All rights reserved. 
${ }^{7}$ EA3808 - NEUVACOD Unité neurovasculaire et troubles cognitifs, Université de Poitiers, Pôle Biologie Santé

${ }^{8}$ Epilepsy Research Centre, Department of Medicine, Austin Health, The University of Melbourne, Heidelberg, Victoria, Australia

${ }^{9}$ INSERM, U 1127, CNRS UMR 7225, Sorbonne Universités, UPMC Univ Paris 06 UMR S 1127, Institut du Cerveau et de la Moelle épinière, ICM, Paris, France

${ }^{10}$ APHP, Hôpital Pitié-Salpêtrière, Département de Génétique et de Cytogénétique; Centre de Reference Déficience Intellectuelle de Causes Rares; GRC UPMC «Déficience Intellectuelle et Autisme», Paris, France.

${ }^{11}$ Service de Génétique, Hospices Civils de Lyon, 69002 Lyon, France

12 Centre de Recherche en Neurosciences de Lyon, INSERM U1028, UMR CNRS 5292, Université Claude Bernard Lyon 1, 69675 Bron Cedex, France.

13 Pediatric Neurology, Neurogenetics and Neurobiology Unit and Laboratories, Neuroscience Department, A Meyer Children's Hospital, University of Florence, Florence, Italy

14 Department of Pediatric Neurology, AP-HP, Hôpital Armand Trousseau, Paris, France

15 Département de génétique et embryologie médicale, Sorbonne Université, GRC $\mathrm{n}^{\circ} 19$, pathologies Congénitales du Cervelet-LeucoDystrophies, Centre de Référence déficiences intellectuelles de causes rares, AP-HP, Hôpital Armand Trousseau, F75012 Paris, France

${ }^{16}$ Clinical genetics, CHU Côte de Nacre, Caen, France

1728 rue de la république 69002 Lyon

${ }^{18}$ GénoPsy, Reference Center for Diagnosis and Management of Genetic Psychiatric Disorders, Centre Hospitalier le Vinatier and EDR-Psy Team (Centre National de la Recherche Scientifique \& Lyon 1 Claude Bernard University)

19 Epileptology Unit and Rehabilitation Unit AP-HP, GH Pitie-Salpêtrière-Charles Foix, F-75013, Paris, France

20 Service de Neurologie Pédiatrie, CHU Amiens-Picardie, Université de Picardie Jules Verne, Amiens France

${ }^{21}$ Département de Neuropédiatrie, CHU Montpellier, Montpellier, France

22 PhyMedExp, U1046 INSERM, UMR9214 CNRS, Université de Montpellier, Montpellier, France

${ }^{23}$ Service de génétique clinique et du Département de Génétique Médicale, Maladies Rares et Médecine Personnalisée, Centre de référence maladies rares anomalies du développement, CHU Montpellier

This article is protected by copyright. All rights reserved. 
${ }^{24}$ Université Montpellier et Unité Inserm U1183, Montpellier, France

${ }^{25}$ Department of Pediatric Neurology, Strasbourg University Hospital, Strasbourg, France

${ }^{26}$ Service de génétique médicale, Hôpitaux Universitaires de Strasbourg, Hôpital de Hautepierre, Strasbourg

${ }^{27}$ Service de pédiatrie, Hôpital Louis-Mourier, Colombes, France

${ }^{28}$ Pediatric Neurology Unit, Centre Hospitalier de Luxembourg, Luxembourg

${ }^{29}$ Pediatric Neurosurgery, Rothschild Foundation Hospital, Paris

${ }^{30}$ Department of Pediatrics, University of Washington, Seattle, WA.

${ }^{31}$ Department of Pediatrics, Division of Genetic Medicine, University of Washington, Seattle, WA.

32 Departments of Neurology and Paediatrics, Royal Children's Hospital, University of Melbourne, Melbourne, Victoria, Australia

${ }^{33}$ Murdoch Children's Research Institute, Melbourne, Victoria, Australia

34 Neurology Department, Center for Clinical Research (CIC 1414), Rennes University Hospital

35 Department of Translational Medical Sciences, Section of Pediatrics-Child Neurology Unit, Federico II University, 80131 Naples, Italy

${ }^{36}$ Department of Pediatric Neurology, C.H.I.R.E.C, Brussels, Belgium

${ }^{37}$ CHU Reims, Hôpital Maison Blanche, Pôle de Biologie, Service de Génétique, Reims, F-51092, France

${ }^{38}$ Reference centre for rare developmental abnormalities CLAD-Ouest, CHU Rennes, France

${ }^{39}$ CNRS UMR 6290 Institut de Génétique et Développement de Rennes IGDR, Univ Rennes, Rennes, France

${ }^{40}$ Department of Paediatrics and Child Health, University of Otago, Wellington, New Zealand

${ }^{41}$ The Florey Institute of Neurosciences and Mental Health, Heidelberg, Victoria, Australia

Address correspondence to:

Rima Nabbout

Reference centre for rare epilepsies

This article is protected by copyright. All rights reserved. 
Department of Pediatric Neurology

Necker Enfants Malades Hospital

149 rue de Sèvres, 75015 Paris, France

Phone: +33 144381536

Email: rimanabbout@yahoo.com

Funding Information

This work was supported by State funding from the Agence Nationale de la Recherche under "Investissements d'avenir" program (ANR-10-IAHU-01) and the Fondation Bettencourt Schueller (CB and RN), the ERC consolidator grant (EK), the Curekids New Zealand and the Health Research Council of New Zealand (LS, IES), the National Health and Medical Research Council of Australia (IES), the European Commission Seventh Framework Programme under the project DESIRE (grant agreement no. 602531, RG).

\begin{abstract}
Developmental and epileptic encephalopathies (DEE) refer to a heterogeneous group of devastating neurodevelopmental disorders. Variants in KCNB1 have been recently reported in patients with early-onset DEE. KCNB1 encodes the alpha subunit of the delayed-rectifier voltage-dependent potassium channel $K_{v} 2.1$. We review the 37 previously reported patients carrying 29 distinct $K C N B 1$ variants and significantly expand the mutational spectrum describing 18 novel variants from 27 unreported patients. Most variants occur de novo and mainly consist of missense variants located on the voltage sensor and the pore domain of $\mathrm{K}_{\mathrm{v}} 2.1$. We also report the first inherited variant (p.Arg583*). KCNB1-related encephalopathies encompass a wide spectrum of neurodevelopmental disorders with predominant language difficulties and behavioral impairment. Eighty-five percent of patients developed epilepsies with variable syndromes and prognosis. Truncating variants in the C-terminal domain are associated with a less severe epileptic phenotype. Overall, this report provides an upto-date review of the mutational and clinical spectrum of $K C N B 1$, strengthening its
\end{abstract}


place as a causal gene in DEEs and emphasizing the need for further functional studies to unravel the underlying mechanisms.

\section{Graphical Abstract}

KCNB1 encodes the alpha subunit of the delayed-rectifier voltage-dependent potassium channel Kv2.1. In this mutation update, we provide an up-to-date review of the mutational and clinical spectrum of the KCNB1 encephalopathy and report 18 novel variants.

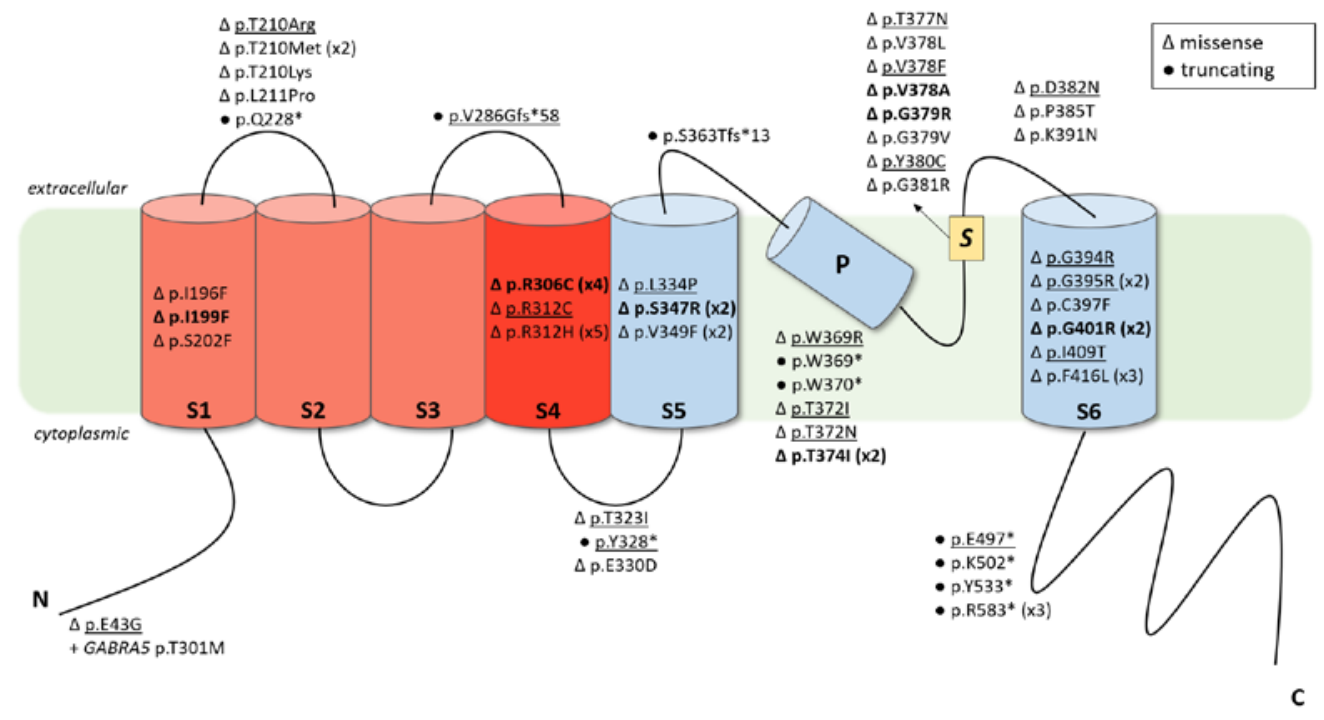

\section{Keywords}

KCNB1, developmental and epileptic encephalopathy, epilepsy, potassium channel

\section{BACKGROUND}

Developmental encephalopathies constitute a broad and genetically heterogeneous group of neurodevelopmental disorders diagnosed during early childhood and persisting throughout life. The clinical spectrum includes variable degrees of social, cognitive, motor, language and behavioral impairments. The concept of “Developmental and Epileptic Encephalopathy” (DEE) refers to the frequently associated epileptic activity (seizures and EEG abnormalities) that contributes to developmental impairment and regression (Scheffer et al., 2017). Recent advances in DNA sequencing methods have highlighted the important role of genes encoding ion channels in the pathogenesis of DEEs (Wang et al., 2017). Ion channels are crucial in 
the generation and modulation of excitability in the nervous system (Wei et al., 2017). “Channelopathies" are associated with a wide phenotypic and genotypic spectrum since one gene is often associated with different phenotypes and variants in several genes might result in the same epilepsy phenotype (McTague et al., 2016; Wei et al., 2017). In particular, gene-related potassium channel dysfunction causes a clinical spectrum of DEEs including epilepsy of infancy with migrating focal seizures (KCNT1), early-onset DEEs with suppression-burst (KCNQ2) and nonspecific DEEs (eg, KCNA2, KCND2, KCND3, KCNH5, KCNJ2, KCNJ10, KCNMA1, KCNQ3, KCNQ5, KCNT2, KCNV2) (Jorge et al., 2011; Sicca et al., 2011; Barcia et al., 2012; Weckhuysen et al., 2012; Veeramah et al., 2013; Ambrosini et al., 2014; Lee et al., 2014; Soldovieri et al., 2014; Pena and Coimbra, 2015; Tabarki et al., 2016; Gururaj et al., 2017; Lehman et al., 2017; Wang et al., 2019).

In 2014, Torkamani et al. identified de novo variants in the potassium voltage-gated channel subfamily B member 1 (KCNB1) in 3 sporadic patients affected by earlyonset DEE. This study provided the initial evidence of the deleterious effect of variants p.Ser347Arg, p.Thr374Ile and p.Gly379Arg on KCNB1 function (Torkamani et al., 2014). Following the initial identification of KCNB1 variants (Torkamani et al., 2014), 29 new KCNB1 variants have been reported in 37 patients detected through next-generation high-throughput sequencing in cohorts of individuals with developmental delay and/or DEE (Soden et al., 2014; Srivastava et al., 2014; Torkamani et al., 2014; Fitzgerald et al., 2015; Saitsu et al., 2015; Thiffault et al., 2015; Allen et al., 2016; de Kovel et al., 2016, 2017; Calhoun et al., 2017; Latypova et al., 2017; Marini et al., 2017; Miao et al., 2017, 2018; Parrini et al., 2017; Zhu et al., 2017; Samanta, 2018). The majority of these patients had epilepsy, intellectual 
disability and behavioral problems (MIM\# 616056; Epileptic encephalopathy, early infantile, 26).

In this mutation update, we aim to present an exhaustive review of patients carrying KCNB1 variants and discuss the evidence for the pathophysiological relevance of these variants. Furthermore, we expand the variant spectrum of KCNB1 with the description of 27 new unrelated patients carrying 18 novel variants.

\section{STRUCTURE OF $K_{\mathrm{v}} 2.1$ CHANNEL}

KCNB1 (MIM\# 600397) is a potassium channel gene located on chromosome 20q13.3 and has a full-length transcript of 11.879 kb (NM_004975) containing 2 exons. KCNB1 protein is a $96 \mathrm{kDa}$ core protein of 858 amino acids forming the alpha subunit of the voltage-gated potassium channel subfamily $2\left(\mathrm{~K}_{\mathrm{v}} 2.1\right) . \mathrm{K}_{\mathrm{v}} 2.1$ channels are expressed across the central nervous system, especially in large clusters on the soma, proximal dendrites and axonal initial segment of neurons (Trimmer, 1991; King et al., 2014). Like other voltage-gated potassium channels, they are composed of four alpha subunits surrounding the ion conduction pore. Each alpha subunit has 6 transmembrane helices (S1-S6) that include a voltage-sensing domain (S1-S4) and a pore domain (S5-P-S6). The voltage-sensor S4 helix contains a series of positively charged amino acids that senses the change in the membrane potential leading to channel opening and closing. The selectivity filter of the pore is formed by the TVGYG amino acids motif located in the re-entrant pore loop between S5 and S6. In addition, $\mathrm{K}_{\mathrm{v}} 2.1$ voltage-gated potassium channels have a $\mathrm{N}$-terminal cytoplasmic region that modulates homotetramerization as well as heterotetramerization with other families of channel-forming subunits, such as the silent alpha subunits $\mathrm{K}_{\mathrm{v}} 6(K C N G)$, $\mathrm{K}_{\mathrm{v}} 8(K C N V)$ and $\mathrm{K}_{\mathrm{v}} 9(K C N S)$ (Xu et al., 1995; Hugnot et al., 1996; Salinas et al., 
1997; Bocksteins et al., 2014). Although the functional role of the intracellular Cterminal domain is yet not fully understood, it mediates the restricted and clustered proximal localization of $\mathrm{K}_{\mathrm{v}} 2.1$ channel (Lim et al., 2000) and interacts with the $\mathrm{N}$ terminal domain to regulate intracellular trafficking, surface expression, voltagedependent activation gating, and phosphorylation-dependent modulation of the $\mathrm{K}_{\mathrm{v}} 2.1$ channel (Ju et al., 2003; Mohapatra et al., 2008). Homotetrameric $\mathrm{K}_{\mathrm{v}} 2.1$ channels mediate a delayed-rectifier voltage-dependent outward potassium current which is essential for membrane repolarization during high-frequency firing. Functional properties of heterotetrameric channels are more complex, depending on the channel subunit composition (Ottschytsch et al., 2002; Sano et al., 2002).

\section{IDENTIFICATION OF KCNB1 VARIANTS}

The database Pubmed was used to search KCNB1 pathogenic variants by combining the terms "KCNB1" and "variants" or "mutations". Articles were reviewed and crossed with KCNB1 variants listed in professional databases (Human Gene Mutation Database HGMD, Biobase, Qiagen). We excluded one patient without Sanger confirmation of de novo inheritance and insufficient clinical data available to validate the variant pathogenicity (Zhu et al., 2017).

We collected 27 new unrelated patients with KCNB1 pathogenic variants through the French reference network for rare epilepsies and international collaborations (Belgium, Italy, Luxembourg, New Zealand and Australia). KCNB1 variants were detected by targeted-Next Generation Sequencing (NGS) panels for either epilepsy or intellectual disability $(n=16)$ or by Whole Exome Sequencing (WES) ( $n=11)$ We classified variants according to the international guidelines of the American College of Medical Genetics (ACMG) Laboratory Practice Committee Working Group (Richards et al., 2015; Supp. Table S1). Single nucleotide variants (SNVs) were 
confirmed by Sanger sequencing and segregation analysis was completed in each family. In silico predictions supporting evidence of pathogenicity for missense variants reported in our 27 new patients are detailed in Supp. Table S2. KCNB1 variants were described according to HGVS variant nomenclature guidelines (http://varnomen.hgvs.org/; Dunnen et al., 2016), using the reference sequence RefSeq NM_ 004975.2. Variants have been submitted to ClinVar database (https://www.ncbi.nlm.nih.gov/clinvar/). Clinical and EEG data were obtained for all patients, including developmental, neurological, behavioral, and epilepsy history, electroencephalogram (EEG) and imaging data when available. All parents or legal guardians gave written informed consent for genetic diagnosis procedures and research participation according to the ethics committee of each institution.

\section{VARIANT SPECTRUM}

We identified 29 pathogenic variants from 37 unrelated patients reported in the literature (Soden et al., 2014; Srivastava et al., 2014; Torkamani et al., 2014; Fitzgerald et al., 2015; Saitsu et al., 2015; Thiffault et al., 2015; Allen et al., 2016; de Kovel et al., 2016, 2017; Calhoun et al., 2017; Latypova et al., 2017; Marini et al., 2017; Miao et al., 2017, 2018; Parrini et al., 2017; Samanta, 2018).

In our cohort of 27 unrelated patients, we found 25 distinct $K C N B 1$ variants including 18 novel variants (Table 1). All patients carried heterozygous missense or truncating variants, arising de novo in $24 / 27$ patients. We report the first inherited variant (p.Arg583*) in patient 64 and his mother affected by intellectual disability without epilepsy. Study of the maternal grandparents showed that the variant occurred de novo in the proband's mother who carried the variation at the heterozygous state. Segregation could not be completed in both parents for the remaining 2 variants in order to confirm their de novo occurrence (patients 51, 58), but both were considered 
pathogenic. The p.Gly395Arg variant in patient 51 was identified as a de novo variant in patient 50 in this series. The p.Phe416Leu variant in patient 58 has been previously reported as likely pathogenic in two patients (Allen et al., 2016; patient 8; de Kovel et al., 2016; ID-2010D05815).

Overall, including our data and those of the literature, we reviewed data of 47 distinct pathogenic variants identified in 64 unrelated patients (Table 1 and Figure 1). All variants except one were in exon 2. They included 37 missense variants (37/47; 79\%), 8 nonsense variants $(8 / 47 ; 17 \%)$ and 2 frameshift variants (2/47; 4\%). Ten variants were recurrent.

Most variants (42/47, 89\%) were located in the S1 to S6 transmembrane segments of the protein. The K+ selectivity filter located between the S5 and S6 transmembrane segments (amino acid 377 to 381) had 8 distinct missense variants, including 3 novel variants in our series. Three were at amino acid position 378 (p.Val378Ala; p.Val378Phe; p.Val378Leu), representing a potential variant hotspot. Two recurrent variants affected the voltage sensor domain. The p.Arg306Cys was found in 4 patients (Patients 12 to 15) and the p.Arg312His was found in 5 patients (Patients 17 to 21). A different amino acid change at this position, p.Arg312Cys, was also found in one patient (Patient 16). Six recurrent variants were localized in the pore domain of the protein (S5 to S6). Two were in the S5 transmembrane segment, each one found in two patients (p.Ser347Arg, patients 26 and 27; p.Val349Phe, patients 28 and 29). The p.Val349Phe variant found in patient 29 resulted from somatic mosaicism (Marini et al., 2017). Three recurrent variants were located in the S6 transmembrane segment. The p.Phe416Leu variant was found in 3 patients (Patients 56 to 58) while the p.Gly395Arg and p.Gly401Arg variants were found in 2 patients each (Patients 50, 51 and 53,54).

This article is protected by copyright. All rights reserved. 
Patient 1 had a KCNB1 variant in the exon 1, affecting the cytoplasmic N-terminal region (p.Glu43Gly). The highly conserved N-terminal domain is a critical determinant for subunit self-association into tetrameric channels and the p.Glu43Gly variant was thus predicted to be damaging (Xu et al., 1995). This patient also carried a de novo variant in GABRA5 gene (MIM\# 137142, p.Thr301Met), which encodes the alpha5 subunit of the gamma-aminobutyric acid type-A $\left(\mathrm{GABA}_{\mathrm{A}}\right)$ receptor. Recently, Butler et al. provided functional evidence of the pathogenic effect of a nearby GABRA5 variant (p.Val294Leu) in a patient with severe DEE (Butler et al., 2018). Therefore, both variants were considered to be contributing to the patient's phenotype.

All variants located within the intracellular C-terminal domain of the protein were truncating. The non-sense variant p.Arg583* was found in 3 unrelated patients (Patients 62 to 64; inherited from the mother in Patient 64). Two other nonsense variants were in the pore helix between S5 and S6 (p.Trp369*; p.Trp370*). The last 4 truncating variants were in the linkers: S1 to S2 linker (p.Gln228*), S3 to S4 linker (p.Val286Glyfs*58), S4 to S5 linker (p.Tyr328*) and S5 to S6 linker (p.Ser363Thrfs*13).

\section{FUNCTIONAL RELEVANCE AND CHARACTERIZATION OF KCNB1 VARIANTS}

To date, seven KCNB1 missense variants have been functionally characterized using different cellular models (Torkamani et al., 2014; Saitsu et al., 2015; Thiffault et al., 2015; Calhoun et al., 2017). Distinct functional effects have been described among studies. The p.Ile199Phe variant, located in the S1 transmembrane segment of the voltage-sensing domain, reduces channel availability due to shift in the voltage 
dependence of activation compared to the wild-type (WT) channel (Calhoun et al., 2017). A variant in the voltage sensor domain S4, p.Arg306Cys, induces currents similar to those in the WT channel but disrupts sensitivity and cooperativity of the sensor while the p.Gly401Arg variant, located in the pore domain S6, has a dominantnegative effect on WT channels and abolishes endogenous currents (Saitsu et al., 2015). Both variants inhibit repetitive neuronal firing by preventing the production of sufficiently deep interspike voltages (Saitsu et al., 2015). Other KCNB1 variants affecting the pore domain result in loss of ion selectivity and gain of inward cation conductance of $\mathrm{K}_{\mathrm{v}} 2.1$ channels (Torkamani et al., 2014; Thiffault et al., 2015). Since these mutants also induce reduced current density at more depolarized voltages, they were predicted to result in depolarized resting membrane potential and impaired membrane repolarization leading to increased cellular excitability (Torkamani et al., 2014). Changes in channel expression and localization were also suggested to contribute to the pathophysiology of $\mathrm{K}_{\mathrm{v}} 2.1$ pore variants (Thiffault et al., 2015). Therefore, given the biophysical properties of these pathogenic variants on $K_{v} 2.1$, they should be considered as loss-of-function rather than gain-of-function.

Finally, delayed rectifier potassium current is diminished in hippocampal neurons cultured from Kcnb1-/- $\left(\mathrm{K}_{\mathrm{v}} 2.1-/-\right)$ mice (Speca et al., 2014). Interestingly, mice lacking $\mathrm{K}_{\mathrm{v}} 2.1$ have no spontaneous seizures but display increased seizure susceptibility in response to proconvulsant drugs and exhibit a range of behavioral disorders associated with marked hyperactivity (Speca et al., 2014).

This article is protected by copyright. All rights reserved. 


\section{EXPANDING THE PHENOTYPIC SPECTRUM OF KCNB1 VARIANTS}

The cohort of 64 patients included 34 males and 28 females (sex ratio M/F 1.2; data available for $n=62 / 64$ ) with pathogenic $K C N B 1$ variants, aged from 1.2 to 33 years (median age at study 8 years, data available for $n=62 / 64$ ).

We report here 6 new patients aged from 8 to 23 years who did not develop seizures (Patients 16, 34, 35, 55, 59, 64).

Overall, 53/63 patients (85\%) developed epilepsy with a median age at seizure onset of 12 months (range: 10 days-5 years, mean 15 months, data available for $n=52 / 53$ ). All patients had developmental delay prior to seizure onset. Thirty-seven patients (70\%) exhibited several seizure types during follow-up, including generalized tonicclonic seizures $(n=28)$, focal seizures $(n=24)$, epileptic spasms $(n=21)$, tonic seizures $(n=14)$, myoclonic seizures $(n=14)$, atypical absences $(n=13)$, atonic seizures $(n=9)$ and clonic seizures $(n=5)$. Nine patients (18\%) developed only epileptic spasms at a mean age of 12 months (range 5-21 months), consistent with the syndrome of infantile spasms (Pavone et al., 2014). Behavioral issues occurred in 37/49 patients with available data (76\%), including autism spectrum disorder in 26 (53\%), aggression in 20 (41\%) and hyperactivity in 12 (24\%).

Developmental delay was reported in all patients with available data $(n=62 / 64)$. A severe expressive language disorder was found in all 42 patients aged 3 years or older in whom some language data was available. Twenty-four patients (57\%) were nonverbal while the remaining were able to speak some words or short sentences. Data on ambulation was available for 43 out of 61 patients aged 2 years or older. Thirty-one patients (72\%) achieved independent walking. Two patients (5\%) aged 11 and 17 
years walked with assistance and 10 patients (23\%) were non-ambulatory. The median age of walking reported for 22/31 patients was 24 months (range 18-54 months). Neurological examination data were available for 52 patients. Hypotonia was the most frequently reported sign ( $n=25 / 52,48 \%)$, followed by spasticity $(n=11$, 21\%), ataxia ( $\mathrm{n}=10,19 \%)$, extrapyramidal symptoms including dystonia and choreiform movements $(n=8,15 \%)$ and hyperlaxity $(n=8,15 \%)$.

Electroencephalographic (EEG) data were available for 51 patients with epilepsy. EEG recordings were characterized by slow background activity, with a combination of multifocal $(n=30)$, focal $(n=12)$ or generalized spikes and/or spikes and waves $(n=23)$. Hypsarrhythmia was reported in 8 children. Sleep activation of EEG abnormalities was found in 13 patients and photosensitivity in 4 patients. Thirty-eight patients (72\%) had pharmacoresistant epilepsy while 13 patients (26\%) responded to antiepileptic drugs. In particular, 6 out of 9 nine patients who developed only infantile spasms became seizure-free with treatment.

Data on brain magnetic resonance imaging (MRI) was available for 54/64 patients. MRI was normal in 42 of the patients carrying KCNB1 variants (78\%). One patient had a normal computed tomography (CT) scan. Mild atrophy was reported in 7 patients and documented as progressive by serial MRIs in 3 of them (Patients 47, 53, 54). Nonspecific periventricular white matter abnormalities were reported in 2 patients (patients 37 and 52) (). One patient had two areas of focal cortical dysplasia associated with focal seizures, multifocal spikes on EEG and responded to carbamazepine (Patient 4). Another patient had small bilateral periventricular heterotopias (Patient 34).

This article is protected by copyright. All rights reserved. 


\section{GENOTYPE-PHENOTYPE CORRELATION}

Patients with KCNB1 variants have a wide phenotypic spectrum including intellectual disability, behavioral disorders and frequent epilepsy. We examined whether the localization or the type of variant correlated with the phenotype.

We reported the first pathogenic variant in the $\mathrm{N}$-terminal domain in a patient who have a DEE with early developmental delay and a seizure onset at 16 months, evolving into severe cognitive impairment and intractable focal and generalized seizures (Patient 1). Interestingly, a pathogenic variant in GABRA5 was also identified in this patient, located in the pore-forming M2 transmembrane domain of the GABA receptor (p.Thr301Met). A nearby pathogenic GABRA5 variant (p.Val294Leu) was reported in a patient with severe developmental delay who differs from our patient as that patient had earlier seizure onset, autistic behavior and spastic quadriparesis (Butler et al., 2018). As both variants (KCNB1 and GABRA5) were predicted to be damaging, a double hit mechanism may be responsible for our patient's phenotype.

In a previous review of 26 patients with a KCNB1 variant, missense variants in the voltage sensor domain or the pore region of the protein were thought to correlate with a more severe phenotype of epilepsy and global developmental delay (de Kovel et al., 2017). Our results show that non-ambulatory patients were more frequent in those with a variant in the S4 to S6 crucial domains ( $n=10 / 31)$ compared to those with a variant in other regions of the protein $(n=0 / 10, p=0,048$, unilateral Fisher's exact test). However, there was no significant difference in terms of epilepsy severity, language acquisition or behavioral issues. In particular, we report here 4 new variants in the S4 to S6 domains in patients with no epilepsy and a moderate developmental delay (Patients 16, 34, 35, 55). This findings does not support a clear correlation of mutations in these domains to the most severe phenotype (de Kovel et al., 2017). The 
epilepsy phenotype was highly variable, as illustrated in patients carrying the same variant. For instance, the recurrent variant p.Arg312His in the voltage sensor domain was associated with infantile spasms (Patient 17 and 18), infantile-onset focal seizures (Patient 19), pharmacoresponsive late-onset focal seizures (Patient 21) and intractable generalized seizures (Patient 20). In addition, a patient carrying a different amino-acid change at the same position (p.Arg312Cys, patient 16) did not develop epilepsy but had a developmental encephalopathy with intellectual disability and behavioral issues. Therefore, no genotype-phenotype correlations can be established based on the localization of the missense variants on the protein domains and more experimental studies are needed to understand the underlying pathophysiology of this phenotype heterogeneity.

Interestingly, all 4 variants found in the C-terminal part of the protein were truncating. While these patients had severe developmental delay and behavioral disorders, 4 out of 6 did not develop seizures (Patients 59, 60, 63, 64) and both patients that developed epilepsy had pharmacoresponsive infantile spasms syndrome (Patients 61). Since all these truncating variants occur within the last exon, they are not anticipated to result in a nonsense-mediated mRNA decay but rather to produce a truncated protein with a potential dominant-negative effect on channel function (Khajavi et al., 2006). Cterminal truncation of $\mathrm{K}_{\mathrm{v}} 2.1$ channel have been shown to impact surface expression, voltage-dependent gating function and phosphorylation-dependent modulation of the channel (Mohapatra et al., 2008; Jensen et al., 2017). Truncated $\mathrm{K}_{\mathrm{v}} 2.1$ channel could thus impact trafficking of tetrameric $\mathrm{K}_{\mathrm{v}} 2.1$ channel to the cell membrane leading to functional consequences on channel properties, as demonstrated in few other channelopathies (Aizawa et al., 2004; Duarri et al., 2015; Mezghrani et al., 2008; Puckerin et al., 2016). Other truncating variants were also in the last exon of the gene 
but located upstream the C-terminal domain, either in extracellular loops or in the pore helix, with no obvious phenotypic difference compared to missense variants. We speculate that they may also escape nonsense-mediated mRNA decay and result in either a non-functional or even deleterious truncated protein missing vital channel domains. Indeed, most functionally studied missense variants displayed a range of dominant-negative effects (Torkamani et al., 2014; Saitsu et al., 2015; Thiffault et al., 2015; Calhoun et al., 2017) that might thus represent the main underlying pathogenic mechanism of KCNB1 variants, as for some other potassium channelopathies-related DEE (Jorge et al., 2011; Orhan et al., 2014; Smets et al., 2015; Masnada et al., 2017). The phenotype severity might be related to the extent of mutation-induced functional $\mathrm{K}_{\mathrm{v}} 2.1$ channel impairment, in addition to other (genetic or environmental) modulating factors that could interact with the mutation during development shaping the phenotype. More electrophysiological studies and animal models are now needed to confirm the pathogenic mechanism of truncating KCNB1 variants.

\section{CLINICAL AND DIAGNOSTIC RELEVANCE}

Even though targeted therapy is not yet available for KCNB1 encephalopathies, genetic diagnosis is important in clinical practice to stop unnecessary diagnostic tests, to correctly inform parents about prognosis and allow accurate genetic counselling.

All the KCNB1 variants identified occurred de novo except in one patient who inherited her p.Arg583* variant from her affected mother. Her mother had intellectual disability with delayed language skills, no reading and writing abilities but could live independently. She did not develop epilepsy. Her 12-year-old daughter did not have seizures but had a severe neurodevelopmental disorder with no language acquisition, autism spectrum disorder and behavioral disorders. We thus report the first inherited KCNB1 variant, associated with intrafamilial variable expressivity. This observation that individuals harboring a KCNB1

This article is protected by copyright. All rights reserved. 
variant with a "less-severe" phenotype can transmit a severe disease is important for accurate interpretation of inherited variants, prenatal diagnosis and genetic counselling.

In addition, patient 1 carrying KCNB1 and GABRA5 variants suggests the co-occurrence of two deleterious variants in the same patient. This 30-year-old patient had a severe phenotype of DEE with social withdrawal, no language acquisition and daily seizures. Additional data from exome and genome studies will enable us to better understand such double hit genotypes and will help in genetic counselling. In some patients, seizure frequency attenuates and disappears over time with prolonged periods of remission and the possibility of withdrawn AEDs (Marini et al., 2017). In this study, we also reported 6 new patients without epilepsy, further strengthening the importance of KCNB1 in neurodevelopmental disorders, beyond DEEs.

\section{CONCLUSIONS AND PERSPECTIVES}

We review the clinical and molecular spectrum of patients with KCNB1 variants through the description of 18 unreported pathogenic variants in 27 new unrelated patients and an exhaustive review of the literature increasing the number of patients to 64 and of pathogenic variants to 47. KCNB1 encephalopathies encompass a wide spectrum of neurodevelopmental disorders, including early-onset global developmental delay with predominant language difficulties and behavioral impairment. Epilepsy is frequent, including the DEEs, but syndrome type and prognosis are variable. Identification of new patients is thus important to fully delineate the phenotypic spectrum of KCNB1 dysfunction. Most variants occur de novo and mainly consist of missense variants with some hotspots located in the voltage sensor and the pore domain of the protein. Few truncating variants are reported with one hotspot in the C-terminal domain associated without epilepsy or with a mild epilepsy. However, available data do not inform further genotype-phenotype correlations, especially in terms of neurodevelopmental outcome. The variety of reported functional effects might contribute to the heterogenous phenotype. Potential modulation by coexisting pathogenic variants in other genes is likely to be another modifier of the phenotype. Beyond the variant effects on ion

This article is protected by copyright. All rights reserved. 
currents, new animal models reproducing KCNB1 variants are needed to explore more accurately the associated pathophysiological mechanisms of disrupted neurodevelopmental pathways and to develop targeted therapies.

\section{ACKNOWLEDGMENTS}

The authors thank the association "KCNB1 France" as well as patients and their families for their participation in this study.

\section{DISCLOSURE STATEMENT}

The authors declare no conflict of interest.

\section{REFERENCES}

Aizawa Y, Ueda K, Wu L-M, Inagaki N, Hayashi T, Takahashi M, Ohta M, Kawano S, Hirano Y, Yasunami M, Aizawa Y, Kimura A, et al. 2004. Truncated KCNQ1 mutant, A178fs/105, forms hetero-multimer channel with wild-type causing a dominant-negative suppression due to trafficking defect. FEBS Lett 574:145-150.

Allen NM, Conroy J, Shahwan A, Lynch B, Correa RG, Pena SDJ, McCreary D, Magalhães TR, Ennis S, Lynch SA, King MD. 2016. Unexplained early onset epileptic encephalopathy: Exome screening and phenotype expansion. Epilepsia 57:e12-17.

Ambrosini E, Sicca F, Brignone MS, D’Adamo MC, Napolitano C, Servettini I, Moro F, Ruan Y, Guglielmi L, Pieroni S, Servillo G, Lanciotti A, et al. 2014. Genetically induced dysfunctions of Kir2.1 channels: implications for short QT3 syndrome and autism-epilepsy phenotype. Hum Mol Genet 23:4875-4886.

Barcia G, Fleming MR, Deligniere A, Gazula V-R, Brown MR, Langouet M, Chen H, Kronengold J, Abhyankar A, Cilio R, Nitschke P, Kaminska A, et al. 2012. De novo 
gain-of-function KCNT1 channel mutations cause malignant migrating partial seizures of infancy. Nat Genet 44:1255-1259.

Bocksteins E, Mayeur E, Van Tilborg A, Regnier G, Timmermans J-P, Snyders DJ. 2014. The subfamily-specific interaction between Kv2.1 and Kv6.4 subunits is determined by interactions between the N- and C-termini. PloS One 9:e98960.

Butler KM, Moody OA, Schuler E, Coryell J, Alexander JJ, Jenkins A, Escayg A. 2018. De novo variants in GABRA2 and GABRA5 alter receptor function and contribute to early-onset epilepsy. Brain 141:2392-2405.

Calhoun JD, Vanoye CG, Kok F, George AL, Kearney JA. 2017. Characterization of a KCNB1 variant associated with autism, intellectual disability, and epilepsy. Neurol Genet 3:e198.

Duarri A, Lin M-CA, Fokkens MR, Meijer M, Smeets CJLM, Nibbeling EAR, Boddeke E, Sinke RJ, Kampinga HH, Papazian DM, Verbeek DS. 2015. Spinocerebellar ataxia type 19/22 mutations alter heterocomplex Kv4.3 channel function and gating in a dominant manner. Cell Mol Life Sci 72:3387-3399.

Dunnen JT den, Dalgleish R, Maglott DR, Hart RK, Greenblatt MS, McGowan Jordan J, Roux A-F, Smith T, Antonarakis SE, Taschner PEM. 2016. HGVS Recommendations for the Description of Sequence Variants: 2016 Update. Hum Mutat 37:564-569.

Fitzgerald T, Gerety S, Jones W, Kogelenberg M van, King D, McRae J, Morley K, Parthiban V, Al-Turki S, Ambridge K, Barrett D, Bayzetinova T, et al. 2015. Largescale discovery of novel genetic causes of developmental disorders. Nature 519:223228.

This article is protected by copyright. All rights reserved. 
Gururaj S, Palmer EE, Sheehan GD, Kandula T, Macintosh R, Ying K, Morris P, Tao J, Dias K-R, Zhu Y, Dinger ME, Cowley MJ, et al. 2017. A de novo mutation in the Sodium-Activated Potassium channel KCNT2 alters ion selectivity and causes epileptic encephalopathy. Cell Rep 21:926-933.

Hugnot JP, Salinas M, Lesage F, Guillemare E, Weille J de, Heurteaux C, Mattéi MG, Lazdunski M. 1996. Kv8.1, a new neuronal potassium channel subunit with specific inhibitory properties towards Shab and Shaw channels. EMBO J 15:3322-3331.

Jensen CS, Watanabe S, Stas JI, Klaphaak J, Yamane A, Schmitt N, Olesen S-P, Trimmer JS, Rasmussen HB, Misonou H. 2017. Trafficking of Kv2.1 Channels to the Axon Initial Segment by a Novel Nonconventional Secretory Pathway. J Neurosci 37:11523-11536.

Jorge BS, Campbell CM, Miller AR, Rutter ED, Gurnett CA, Vanoye CG, George AL, Kearney JA. 2011. Voltage-gated potassium channel KCNV2 (Kv8.2) contributes to epilepsy susceptibility. Proc Natl Acad Sci U S A 108:5443-5448.

Ju M, Stevens L, Leadbitter E, Wray D. 2003. The Roles of N- and C-terminal determinants in the activation of the Kv2.1 potassium channel. J Biol Chem 278:12769-12778.

Khajavi M, Inoue K, Lupski JR. 2006. Nonsense-mediated mRNA decay modulates clinical outcome of genetic disease. Eur J Hum Genet 14:1074.

King AN, Manning CF, Trimmer JS. 2014. A Unique Ion Channel Clustering Domain on the Axon Initial Segment of Mammalian Neurons. J Comp Neurol 522:2594-2608.

This article is protected by copyright. All rights reserved. 
Kovel CGF de, Brilstra EH, Kempen MJA van, Slot R van‘t, Nijman IJ, Afawi Z, De Jonghe P, Djémié T, Guerrini R, Hardies K, Helbig I, Hendrickx R, et al. 2016. Targeted sequencing of 351 candidate genes for epileptic encephalopathy in a large cohort of patients. Mol Genet Genomic Med 4:568-580.

Kovel CGF de, Syrbe S, Brilstra EH, Verbeek N, Kerr B, Dubbs H, Bayat A, Desai S, Naidu S, Srivastava S, Cagaylan H, Yis U, et al. 2017. Neurodevelopmental Disorders Caused by De Novo Variants in KCNB1 Genotypes and Phenotypes. JAMA Neurol 74:1228.

Latypova X, Matsumoto N, Vinceslas-Muller C, Bézieau S, Isidor B, Miyake N. 2017. Novel KCNB1 mutation associated with non-syndromic intellectual disability. J Hum Genet 62:569-573.

Lee H, Lin MA, Kornblum HI, Papazian DM, Nelson SF. 2014. Exome sequencing identifies de novo gain of function missense mutation in KCND2 in identical twins with autism and seizures that slows potassium channel inactivation. Hum Mol Genet 23:3481-3489.

Lehman A, Thouta S, Mancini GMS, Naidu S, Slegtenhorst M van, McWalter K, Person R, Mwenifumbo J, Salvarinova R, CAUSES Study, EPGEN Study, Guella I, et al. 2017. Loss-of-Function and Gain-of-Function Mutations in KCNQ5 Cause Intellectual Disability or Epileptic Encephalopathy. Am J Hum Genet 101:65-74.

Lim ST, Antonucci DE, Scannevin RH, Trimmer JS. 2000. A novel targeting signal for proximal clustering of the Kv2.1 K+ channel in hippocampal neurons. Neuron 25:385-397.

This article is protected by copyright. All rights reserved. 
Marini C, Romoli M, Parrini E, Costa C, Mei D, Mari F, Parmeggiani L, Procopio E, Metitieri T, Cellini E, Virdò S, De Vita D, et al. 2017. Clinical features and outcome of 6 new patients carrying de novo KCNB1 gene mutations. Neurol Genet 3:.

Masnada S, Hedrich UBS, Gardella E, Schubert J, Kaiwar C, Klee EW, Lanpher BC, Gavrilova RH, Synofzik M, Bast T, Gorman K, King MD, et al. 2017. Clinical spectrum and genotype-phenotype associations of KCNA2-related encephalopathies. Brain 140:2337-2354.

Mastrangelo M. 2015. Novel Genes of Early-Onset Epileptic Encephalopathies: From Genotype to Phenotypes. Pediatr Neurol 53:119-129.

McTague A, Howell KB, Cross JH, Kurian MA, Scheffer IE. 2016. The genetic landscape of the epileptic encephalopathies of infancy and childhood. Lancet Neurol 15:304-316.

Mezghrani A, Monteil A, Watschinger K, Sinnegger-Brauns MJ, Barrère C, Bourinet E, Nargeot J, Striessnig J, Lory P. 2008. A destructive interaction mechanism accounts for dominant-negative effects of misfolded mutants of voltage-gated calcium channels. J Neurosci Off J Soc Neurosci 28:4501-4511.

Miao P, Feng J, Guo Y, Wang J, Xu X, Wang Y, Li Y, Gao L, Zheng C, Cheng H. 2018. Genotype and phenotype analysis using an epilepsy-associated gene panel in Chinese pediatric epilepsy patients. Clin Genet 94:512-520.

Miao P, Peng J, Chen C, Gai N, Yin F. 2017. A novel mutation in KCNB1 gene in a child with neuropsychiatric comorbidities with both intellectual disability and epilepsy and review of literature. Zhonghua Er Ke Za Zhi Chin J Pediatr 55:115-119.

This article is protected by copyright. All rights reserved. 
Mohapatra DP, Siino DF, Trimmer JS. 2008. Interdomain Cytoplasmic Interactions Govern the Intracellular Trafficking, Gating, and Modulation of the Kv2.1 Channel. J Neurosci Off J Soc Neurosci 28:4982-4994.

Orhan G, Bock M, Schepers D, Ilina EI, Reichel SN, Löffler H, Jezutkovic N, Weckhuysen S, Mandelstam S, Suls A, Danker T, Guenther E, et al. 2014. Dominantnegative effects of KCNQ2 mutations are associated with epileptic encephalopathy. Ann Neurol 75:382-394.

Ottschytsch N, Raes A, Van Hoorick D, Snyders DJ. 2002. Obligatory heterotetramerization of three previously uncharacterized Kv channel alpha-subunits identified in the human genome. Proc Natl Acad Sci U S A 99:7986-7991.

Parrini E, Marini C, Mei D, Galuppi A, Cellini E, Pucatti D, Chiti L, Rutigliano D, Bianchini C, Virdò S, De Vita D, Bigoni S, et al. 2017. Diagnostic Targeted Resequencing in 349 Patients with Drug-Resistant Pediatric Epilepsies Identifies Causative Mutations in 30 Different Genes: HUMAN MUTATION. Hum Mutat 38:216-225.

Pavone P, Striano P, Falsaperla R, Pavone L, Ruggieri M. 2014. Infantile spasms syndrome, West syndrome and related phenotypes: What we know in 2013. Brain Dev 36:739-751.

Pena SDJ, Coimbra RLM. 2015. Ataxia and myoclonic epilepsy due to a heterozygous new mutation in KCNA2 : proposal for a new channelopathy: Ataxia and myoclonic epilepsy due to a heterozygous new mutation. Clin Genet 87:e1-e3.

This article is protected by copyright. All rights reserved. 
Puckerin A, Aromolaran KA, Chang DD, Zukin RS, Colecraft HM, Boutjdir M, Aromolaran AS. 2016. hERG 1a LQT2 C-terminus truncation mutants display hERG 1b-dependent dominant negative mechanisms. Heart Rhythm 13:1121-1130.

Richards S, Aziz N, Bale S, Bick D, Das S, Gastier-Foster J, Grody WW, Hegde M, Lyon E, Spector E, Voelkerding K, Rehm HL, et al. 2015. Standards and guidelines for the interpretation of sequence variants: a joint consensus recommendation of the American College of Medical Genetics and Genomics and the Association for Molecular Pathology. Genet Med Off J Am Coll Med Genet 17:405-424.

Saitsu H, Akita T, Tohyama J, Goldberg-Stern H, Kobayashi Y, Cohen R, Kato M, Ohba C, Miyatake S, Tsurusaki Y, Nakashima M, Miyake N, et al. 2015. De novo KCNB1 mutations in infantile epilepsy inhibit repetitive neuronal firing. Sci Rep 5:.

Salinas M, Duprat F, Heurteaux C, Hugnot JP, Lazdunski M. 1997. New modulatory alpha subunits for mammalian Shab K+ channels. J Biol Chem 272:24371-24379.

Samanta D. 2018. Epileptic spasm and de novo KCNB1 mutation: if it is not one potassium channel, it is another! Acta Neurol Belg.

Sano Y, Mochizuki S, Miyake A, Kitada C, Inamura K, Yokoi H, Nozawa K, Matsushime H, Furuichi K. 2002. Molecular cloning and characterization of Kv6.3, a novel modulatory subunit for voltage-gated K(+) channel Kv2.1. FEBS Lett 512:230234.

Scheffer IE, Berkovic S, Capovilla G, Connolly MB, French J, Guilhoto L, Hirsch E, Jain S, Mathern GW, Moshé SL, Nordli DR, Perucca E, et al. 2017. ILAE classification of the epilepsies: Position paper of the ILAE Commission for Classification and Terminology. Epilepsia 58:512-521.

This article is protected by copyright. All rights reserved. 
Sicca F, Imbrici P, D’Adamo MC, Moro F, Bonatti F, Brovedani P, Grottesi A, Guerrini R, Masi G, Santorelli FM, Pessia M. 2011. Autism with seizures and intellectual disability: possible causative role of gain-of-function of the inwardlyrectifying K+ channel Kir4.1. Neurobiol Dis 43:239-247.

Smets K, Duarri A, Deconinck T, Ceulemans B, Warrenburg BP van de, Züchner S, Gonzalez MA, Schüle R, Synofzik M, Van der Aa N, De Jonghe P, Verbeek DS, et al. 2015. First de novo KCND3 mutation causes severe Kv4.3 channel dysfunction leading to early onset cerebellar ataxia, intellectual disability, oral apraxia and epilepsy. BMC Med Genet 16:

Soden SE, Saunders CJ, Willig LK, Farrow EG, Smith LD, Petrikin JE, LePichon JB, Miller NA, Thiffault I, Dinwiddie DL, Twist G, Noll A, et al. 2014. Effectiveness of exome and genome sequencing guided by acuity of illness for diagnosis of neurodevelopmental disorders. Sci Transl Med 6:265ra168.

Soldovieri MV, Boutry-Kryza N, Milh M, Doummar D, Heron B, Bourel E, Ambrosino P, Miceli F, De Maria M, Dorison N, Auvin S, Echenne B, et al. 2014. Novel KCNQ2 and KCNQ3 mutations in a large cohort of families with benign neonatal epilepsy: first evidence for an altered channel regulation by syntaxin-1A. Hum Mutat 35:356-367.

Speca DJ, Ogata G, Mandikian D, Bishop HI, Wiler SW, Eum K, Wenzel HJ, Doisy ET, Matt L, Campi KL, Golub MS, Nerbonne JM, et al. 2014. Deletion of the Kv2.1 delayed rectifier potassium channel leads to neuronal and behavioral hyperexcitability. Genes Brain Behav 13:394-408.

This article is protected by copyright. All rights reserved. 
Srivastava S, Cohen JS, Vernon H, Barañano K, McClellan R, Jamal L, Naidu S, Fatemi A. 2014. Clinical whole exome sequencing in child neurology practice. Ann Neurol 76:473-483.

Tabarki B, AlMajhad N, AlHashem A, Shaheen R, Alkuraya FS. 2016. Homozygous KCNMA1 mutation as a cause of cerebellar atrophy, developmental delay and seizures. Hum Genet 135:1295-1298.

Thiffault I, Speca DJ, Austin DC, Cobb MM, Eum KS, Safina NP, Grote L, Farrow EG, Miller N, Soden S, Kingsmore SF, Trimmer JS, et al. 2015. A novel epileptic encephalopathy mutation in KCNB1 disrupts Kv2.1 ion selectivity, expression, and localization. J Gen Physiol 146:399-410.

Torkamani A, Bersell K, Jorge BS, Bjork RL, Friedman JR, Bloss CS, Cohen J, Gupta S, Naidu S, Vanoye CG, George AL, Kearney JA. 2014. De novo KCNB1 mutations in epileptic encephalopathy. Ann Neurol 76:529-540.

Trimmer JS. 1991. Immunological identification and characterization of a delayed rectifier K+ channel polypeptide in rat brain. Proc Natl Acad Sci U S A 88:1076410768.

Veeramah KR, Johnstone L, Karafet TM, Wolf D, Sprissler R, Salogiannis J, BarthMaron A, Greenberg ME, Stuhlmann T, Weinert S, Jentsch TJ, Pazzi M, et al. 2013. Exome sequencing reveals new causal mutations in children with epileptic encephalopathies. Epilepsia 54:1270-1281.

Wang J, Lin Z-J, Liu L, Xu H-Q, Shi Y-W, Yi Y-H, He N, Liao W-P. 2017. Epilepsyassociated genes. Seizure 44:11-20.

This article is protected by copyright. All rights reserved. 
Wang J, Wen Y, Zhang Q, Yu S, Chen Y, Wu X, Zhang Y, Bao X. 2019. Gene mutational analysis in a cohort of Chinese children with unexplained epilepsy: Identification of a new KCND3 phenotype and novel genes causing Dravet syndrome. Seizure 66:26-30.

Weckhuysen S, Mandelstam S, Suls A, Audenaert D, Deconinck T, Claes LRF, Deprez L, Smets K, Hristova D, Yordanova I, Jordanova A, Ceulemans B, et al. 2012. KCNQ2 encephalopathy: emerging phenotype of a neonatal epileptic encephalopathy. Ann Neurol 71:15-25.

Wei F, Yan L-M, Su T, He N, Lin Z-J, Wang J, Shi Y-W, Yi Y-H, Liao W-P. 2017. Ion Channel Genes and Epilepsy: Functional Alteration, Pathogenic Potential, and Mechanism of Epilepsy. Neurosci Bull 33:455-477.

Xu J, Yu W, Jan YN, Jan LY, Li M. 1995. Assembly of Voltage-gated Potassium Channels CONSERVED HYDROPHILIC MOTIFS DETERMINE SUBFAMILYSPECIFIC INTERACTIONS BETWEEN THE $\alpha$-SUBUNITS. J Biol Chem 270:24761-24768.

Zhu X, Padmanabhan R, Copeland B, Bridgers J, Ren Z, Kamalakaran S, O’DriscollCollins A, Berkovic SF, Scheffer IE, Poduri A, Mei D, Guerrini R, et al. 2017. A case-control collapsing analysis identifies epilepsy genes implicated in trio sequencing studies focused on de novo mutations. PLOS Genet 13:e1007104.

This article is protected by copyright. All rights reserved. 


\section{Figure}

\section{Figure 1}

Schematic representation of $\mathrm{K}_{\mathrm{v}} 2.1$ protein structure and location of KCNB1 previously described and novel variants. Variants are displayed as changes at protein level (p). Underlined variants correspond to novel variants reported for the first time in this report. For recurrent variants, the number of reported patients is indicated between parentheses next to the variant. Triangles and black circles respectively indicate missense variants and truncating variants (frameshift or nonsense variants). Variants where functional studies have been previously conducted are indicated in bold. Functional domains are represented by N: N-terminal domain (residues 1-186), S1: Segment S1 (residues 187-208), S2: Segment S2 (residues 229-250), S3: Segment S3 (residues 260-280), S4: Segment S4 (residues 295-316), S5: Segment S5 (residues 331-351), P: pore helix (residues 365-376), S: Selectivity filter (residues 377-381),

S6: Segment S6 (residues 392-420), C: C-terminal domain (residues 421-858).

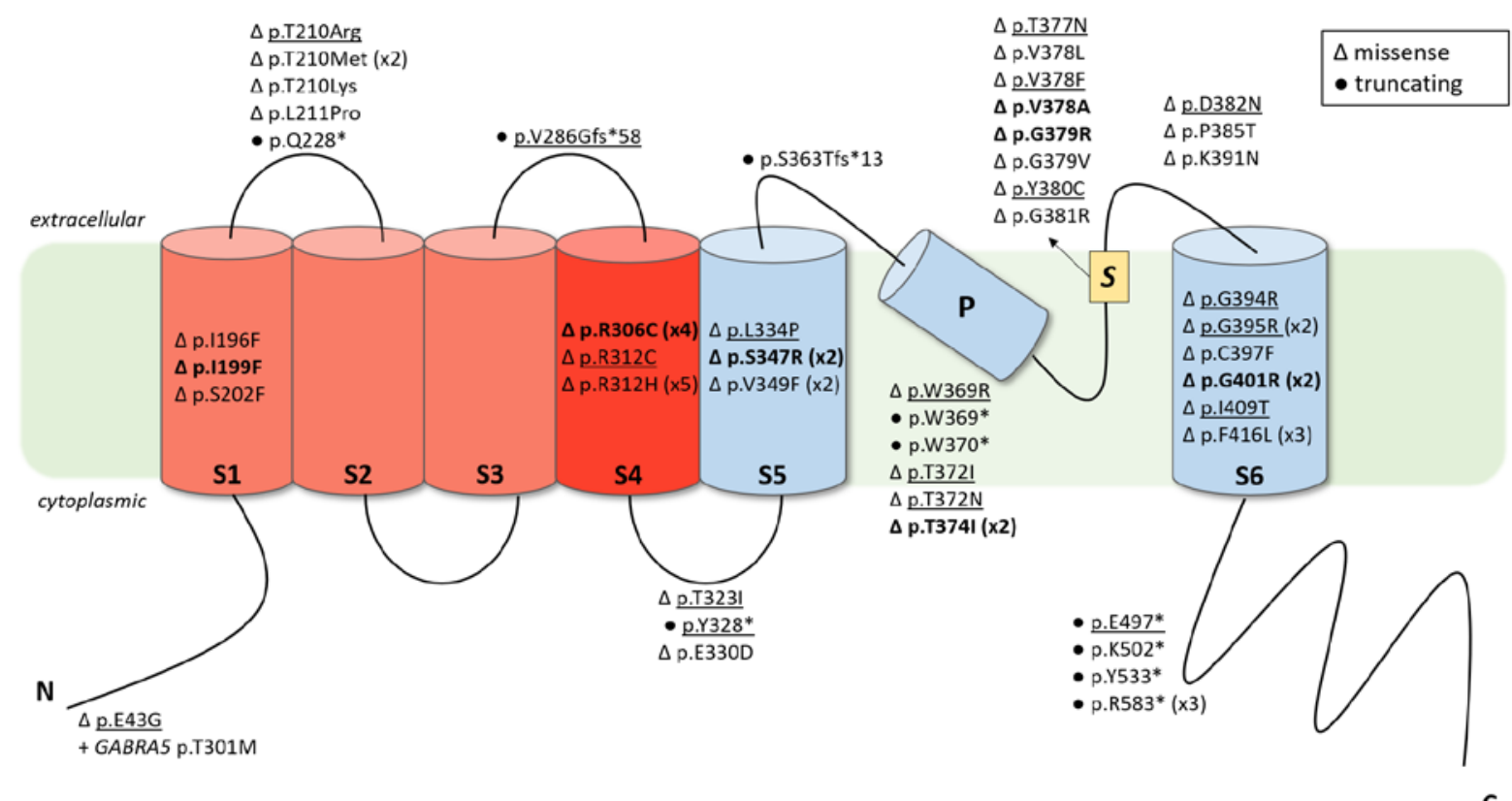

This article is protected by copyright. All rights reserved. 


\section{DATA AVAILABILITY STATEMENT}

The data that support the findings of this study are available on request from the corresponding author. The data are not publicly available due to privacy or ethical restrictions.

Table 1. KCNB1 genotype and clinical features of patients in our cohort and the literature.

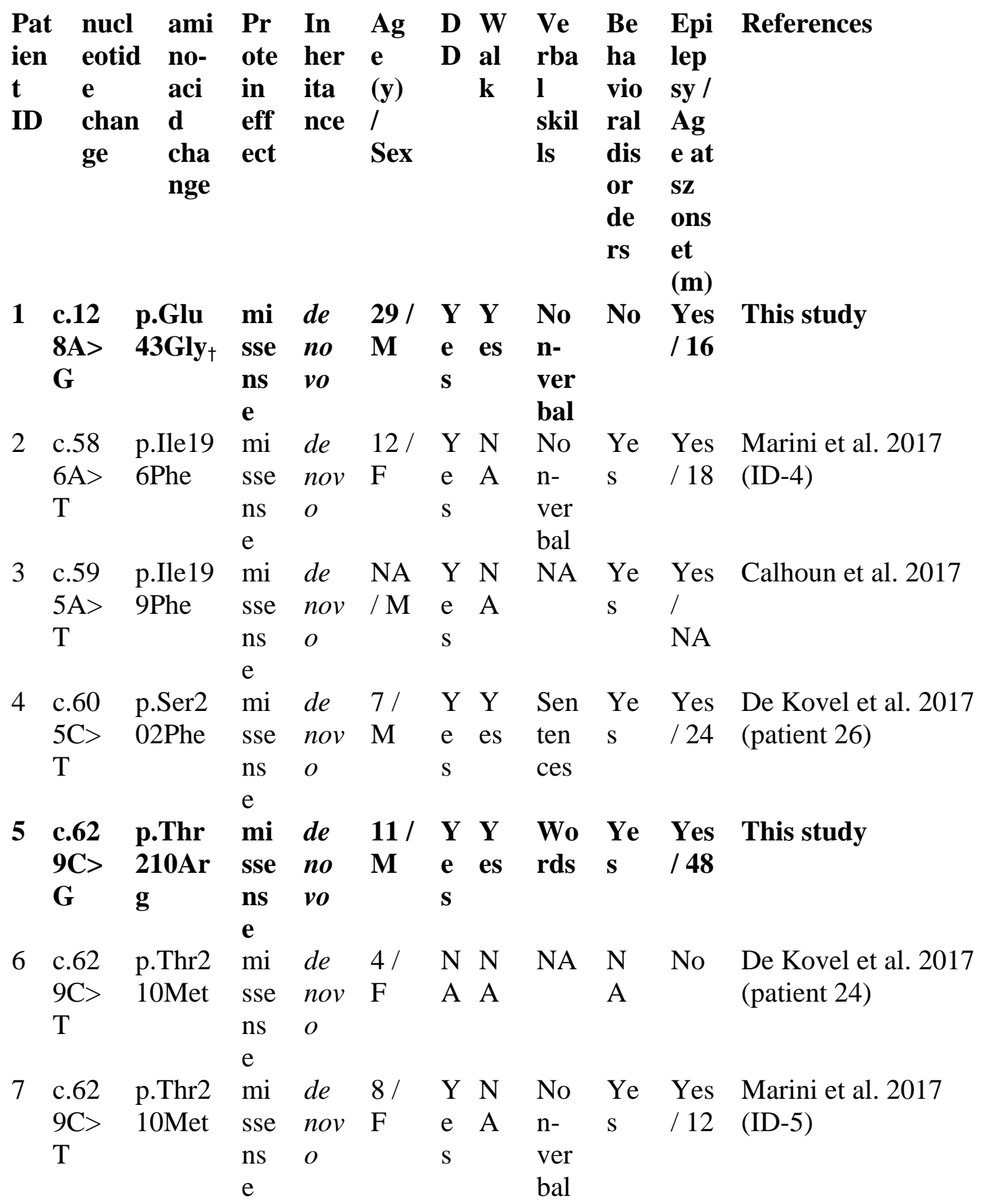


8 c.62 p.Thr2 mi de $7 / \quad$ Y $\quad$ Y $\quad$ Sen $\quad$ Ye $\quad$ Yes De Kovel et al. 2017 9C $>$ 10Lys sse nov $\mathrm{M}$ e es ten $\mathrm{s} / 4$ (patient 25)
A ns $O \quad$ s ces
9 c.63 p.Leu2 mi de $7 / \quad$ Y $\quad \mathrm{N}$ NA No Yes De Kovel et al. 2017 2T> 11Pro sse nov $\mathrm{F}$ e A $\quad / 11$ (patient 23)
C ns $O \quad$ s

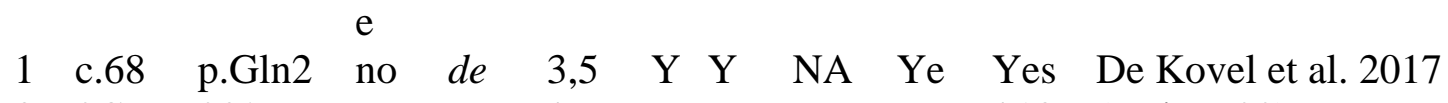

0 2C> 28* ns nov /F e es $\quad$ s $/ 10$ (patient 22)

$\begin{array}{llll}\mathrm{T} & \text { en } O & \mathrm{~S}\end{array}$
$\begin{array}{llllllllllll}1 & \text { c.85 p.Val2 fra de } & 2 / & \text { Y } & \text { Y } & \text { Sen } & \text { No } & \text { Yes } & \text { This study }\end{array}$
1 7del 86Gly me no $M$ e es ten $/ 5$
fs*58 shi vo $\quad$ s $\quad$ ces

1 c.91 p.Arg3 mi de $8 / \quad$ Y $\quad$ Y Sen $\quad$ Ye $\quad$ Yes This study

2 6C $>$ 06Cys sse nov $\mathrm{F}$ e es ten $\mathrm{s} \quad / 48$

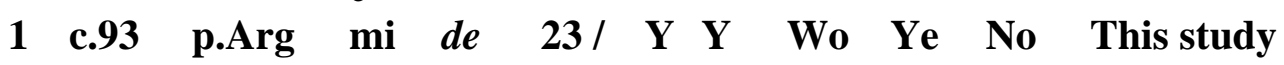

$64 \mathrm{C}>312 \mathrm{Cy}$ sse no $M$ e es $\mathrm{rds} \mathrm{s}$ $\begin{array}{llllll}\mathbf{T} & \mathbf{s} & \mathbf{n s} & \text { vo } & \mathbf{s}\end{array}$

1 c.93 p.Arg3 mi de 9/ Y Y No Ye Yes De Kovel et al. 2017

7 5G> 12His sse nov $\mathrm{M}$ e es $\mathrm{n}^{-} \mathrm{s} \quad / 10$ (patient 19) $\mathrm{A}$ ns $O$
ver
1 c.93 p.Arg3 $\begin{array}{lllllllll}\mathrm{e} i & \text { de } & 1,2 & \mathrm{Y} & \mathrm{N} & \text { No } & \mathrm{N} & \text { Yes } & \text { Samanta et al. } 2018\end{array}$
8 5G> 12His sse nov /F e o n- A / 14
A ns $o$ s ver
1 c.93 p.Arg3 mi NA $11 /$ Y N No Ye Yes De Kovel et al. 2016
$95 \mathrm{G}>12 \mathrm{His}$ sse $\mathrm{M}$ e $\mathrm{o}$ n- $\mathrm{s} / 14$ (ID-KIEL20), De A $\quad$ ns $\quad$ s ver $\quad$ Kovel et al. 2017 e bal (patient 18)
2 c.93 p.Arg3 mi de $33 / \mathrm{Y} \quad \mathrm{Y}$ No $\mathrm{Ye}$ Yes This study
0 5G> 12His sse nov $\mathrm{M}$ e es $\mathrm{n}-\mathrm{s}$ / 18

This article is protected by copyright. All rights reserved. 


\begin{tabular}{|c|c|c|c|c|c|c|c|c|c|c|c|}
\hline & A & & $\begin{array}{l}\text { ns } \\
\mathrm{e}\end{array}$ & $o$ & & $\mathrm{~s}$ & & $\begin{array}{l}\text { ver } \\
\text { bal }\end{array}$ & & & \\
\hline 2 & c.93 & p.Arg3 & $\mathrm{mi}$ & de & $13 /$ & $\mathrm{Y}$ & $\mathrm{Y}$ & No & $\mathrm{Ye}$ & Yes & This study \\
\hline \multirow[t]{2}{*}{1} & $5 \mathrm{G}>$ & $12 \mathrm{His}$ & sse & nov & M & $\mathrm{e}$ & es & n- & $\mathrm{s}$ & $/ 60$ & \\
\hline & A & & $\begin{array}{l}\text { ns } \\
\mathrm{e}\end{array}$ & $o$ & & $\mathrm{~s}$ & & $\begin{array}{l}\text { ver } \\
\text { bal }\end{array}$ & & & \\
\hline 2 & c.96 & p.Thr & mi & de & $3 /$ & $\mathbf{Y}$ & $\mathbf{Y}$ & No & Ye & Yes & This study \\
\hline \multirow[t]{2}{*}{2} & $8 C>$ & 323Ile & sse & no & $\mathbf{M}$ & $\mathbf{e}$ & es & n- & $\mathbf{s}$ & / 21 & \\
\hline & $\mathbf{T}$ & & $\begin{array}{l}\text { ns } \\
\mathbf{e}\end{array}$ & vo & & $\mathbf{S}$ & & $\begin{array}{l}\text { ver } \\
\text { bal }\end{array}$ & & & \\
\hline 2 & c.98 & p.Tyr & no & de & 4,5 & $\mathbf{Y}$ & $\mathbf{Y}$ & Wo & Ye & Yes & This study \\
\hline \multirow[t]{2}{*}{3} & $4 C>$ & $328 *$ & ns & no & $/ \mathbf{F}$ & $\mathbf{e}$ & es & rds & $\mathbf{s}$ & $/ 7$ & \\
\hline & $\mathbf{G}$ & & $\begin{array}{l}\text { en } \\
\text { se }\end{array}$ & vo & & $\mathbf{s}$ & & & & & \\
\hline 2 & c.99 & p.Glu3 & $\mathrm{mi}$ & $d e$ & 3,6 & $\mathrm{Y}$ & $\mathrm{N}$ & NA & $\mathrm{N}$ & Yes & Miao et al. 2018 \\
\hline \multirow[t]{2}{*}{4} & $0 \mathrm{G}>$ & 30Asp & sse & nov & $/ \mathrm{F}$ & $\mathrm{e}$ & A & & A & / 18 & \\
\hline & $\mathrm{C}$ & & $\begin{array}{l}\text { ns } \\
\mathrm{e}\end{array}$ & $O$ & & $\mathrm{~s}$ & & & & & \\
\hline 2 & c.10 & p.leu3 & mi & de & $5 /$ & $\mathbf{Y}$ & $\mathbf{N}$ & No & Ye & Yes & This study \\
\hline \multirow[t]{2}{*}{5} & $01 T$ & 34Pro & sse & no & $\mathbf{F}$ & $\mathbf{e}$ & $\mathbf{0}$ & n- & $\mathbf{s}$ & / 24 & \\
\hline & $>\mathrm{C}$ & & $\begin{array}{l}\text { ns } \\
\mathbf{e}\end{array}$ & vo & & $\mathbf{s}$ & & $\begin{array}{l}\text { ver } \\
\text { bal }\end{array}$ & & & \\
\hline 2 & c. 10 & p.Ser3 & $\mathrm{mi}$ & de & $10 /$ & $\mathrm{Y}$ & $\mathrm{Y}$ & Sen & $\mathrm{Ye}$ & Yes & This study \\
\hline \multirow[t]{2}{*}{6} & $41 \mathrm{C}$ & 47Arg & sse & nov & $\mathrm{M}$ & $\mathrm{e}$ & es & ten & s & / 18 & \\
\hline & $>G$ & & $\begin{array}{l}\text { ns } \\
\mathrm{e}\end{array}$ & $O$ & & $\mathrm{~s}$ & & ces & & & \\
\hline 2 & c. 10 & p.Ser3 & $\mathrm{mi}$ & de & $9 /$ & $\mathrm{Y}$ & $\mathrm{Y}$ & NA & $\mathrm{N}$ & Yes & Torkamani et al. \\
\hline \multirow[t]{2}{*}{7} & $41 \mathrm{C}$ & 47Arg & sse & nov & $\mathrm{F}$ & $\mathrm{e}$ & es & & $\mathrm{A}$ & / 48 & 2014 (ID-9), De \\
\hline & $>\mathrm{A}$ & & $\begin{array}{l}\text { ns } \\
\mathrm{e}\end{array}$ & $o$ & & $\mathrm{~s}$ & & & & & $\begin{array}{l}\text { Kovel et al. } 2017 \\
\text { (Patient 17) }\end{array}$ \\
\hline 2 & c. 10 & p.Val3 & $\mathrm{mi}$ & de & 1,6 & $\mathrm{Y}$ & $\mathrm{N}$ & No & Ye & Yes & This study \\
\hline \multirow[t]{2}{*}{8} & $45 G$ & 49Phe & sse & nov & $/ \mathrm{F}$ & $\mathrm{e}$ & 0 & $n-$ & $\mathrm{s}$ & $/ 9$ & \\
\hline & $>\mathrm{T}$ & & $\begin{array}{l}\text { ns } \\
\mathrm{e}\end{array}$ & $O$ & & $\mathrm{~s}$ & & $\begin{array}{l}\text { ver } \\
\text { bal }\end{array}$ & & & \\
\hline 2 & c. 10 & p.Val3 & $\mathrm{mi}$ & de & $17 /$ & $\mathrm{Y}$ & $\mathrm{N}$ & Wo & $\mathrm{Ye}$ & Yes & Marini et al. 2017 \\
\hline \multirow[t]{2}{*}{9} & $45 G$ & 49Phe & sse & nov & $\mathrm{M}$ & $\mathrm{e}$ & A & rds & s & / 11 & (ID-6) \\
\hline & $>\mathrm{T}$ & & $\begin{array}{l}\text { ns } \\
\mathrm{e}\end{array}$ & $o$ & & $\mathrm{~s}$ & & & & & \\
\hline 3 & c. 10 & p.Ser3 & fra & de & $2 /$ & $\mathrm{Y}$ & $\mathrm{N}$ & No & No & Yes & De Kovel et al. 2017 \\
\hline \multirow[t]{2}{*}{0} & 88de & 63Thrf & me & nov & $\mathrm{M}$ & $\mathrm{e}$ & A & $n-$ & & / 14 & (patient 16) \\
\hline & $\mathrm{lG}$ & $\mathrm{s} * 13$ & $\begin{array}{l}\text { shi } \\
\mathrm{ft}\end{array}$ & $o$ & & $\mathrm{~s}$ & & $\begin{array}{l}\text { ver } \\
\text { bal }\end{array}$ & & & \\
\hline 3 & c.11 & p.Trp & mi & de & $14 /$ & $\mathbf{Y}$ & $\mathbf{N}$ & No & Ye & Yes & This study \\
\hline \multirow[t]{2}{*}{1} & $05 T$ & 369Ar & sse & no & $\mathbf{M}$ & $\mathbf{e}$ & $\mathbf{0}$ & n- & $\mathbf{s}$ & / 10 & \\
\hline & $>\mathrm{C}$ & g & $\begin{array}{l}\text { ns } \\
\text { e }\end{array}$ & vo & & $\mathbf{s}$ & & $\begin{array}{l}\text { ver } \\
\text { bal }\end{array}$ & & & \\
\hline 3 & c.11 & p.Trp3 & no & de & $5 /$ & $\mathrm{Y}$ & $\mathrm{N}$ & NA & $\mathrm{Ye}$ & Yes & De Kovel et al. 2017 \\
\hline \multirow[t]{2}{*}{2} & 07G & $69 *$ & ns & nov & $\mathrm{M}$ & $\mathrm{e}$ & A & & s & / 18 & (patient 15) \\
\hline & $>\mathrm{A}$ & & $\begin{array}{l}\text { en } \\
\text { se }\end{array}$ & $O$ & & $\mathrm{~s}$ & & & & & \\
\hline
\end{tabular}

This article is protected by copyright. All rights reserved. 
$\begin{array}{llllllllllll}3 & \text { c.11 } & \text { p.Trp3 } & \text { no } & \text { de } & 7 / & \text { Y } & \text { N } & \text { Wo } & \text { No } & \text { Yes } & \text { Parrini et al. } 2017 \\ 3 & \text { 09G } & 70^{*} & \text { ns } & \text { nov } & \text { M } & \text { e } & \text { A } & \text { rds } & & \text { / } 9 & \text { Marini et al. } 2017 \\ & \text { >A } & & \text { en } & o & & \text { s } & & & & & \text { (ID-1) }\end{array}$

$$
\text { se }
$$

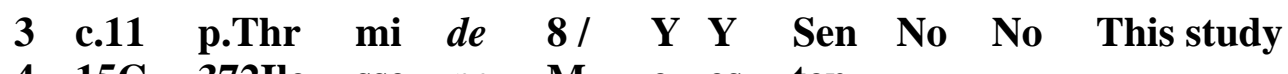

4 15C 372Ile sse no $M$ e es ten

$>T$ ns vo $\quad$ s ces

$\begin{array}{llllllllllll}3 & \text { c.11 } & \text { p.Thr } & \text { mi } & \text { de } & 12 / & \text { Y } & \text { Y } & \text { Sen } & \text { Ye } & \text { No } & \text { This study } \\ 5 & 15 C & 372 A s & \text { sse } & \text { no } & \text { F } & \text { e } & \text { es } & \text { ten } & \text { s } & & \end{array}$

$\begin{array}{lllllllll}5 & 15 C & 372 A s & \text { sse } & \text { no } & \text { F } & \text { e } & \text { es } & \text { ten } \\ >\text { A } & \text { n } & \text { ns } & \text { vo } & & \text { s } & & \text { ces }\end{array}$

3 c.11 p.Thr3 mi de $5 / \quad$ Y $\quad \mathrm{N} \quad \mathrm{NA} \quad \mathrm{N} \quad$ Yes Allen et al. 2013

6 21C 74Ile sse nov F e A $>\mathrm{T}$ ns 0 S e 2014 (patient 3), De

Kovel et al. 2017 (patient 13)

3 c.11 p.Thr3 mi de 11/ Y W No Ye Yes De Kovel et al. 2017

7 21C 74Ile sse nov $\mathrm{F}$ e ith $\mathrm{n}^{-} \mathrm{s} / 13$ (patient 14) $>\mathrm{T} \quad$ ns $O \quad$ s ai ver

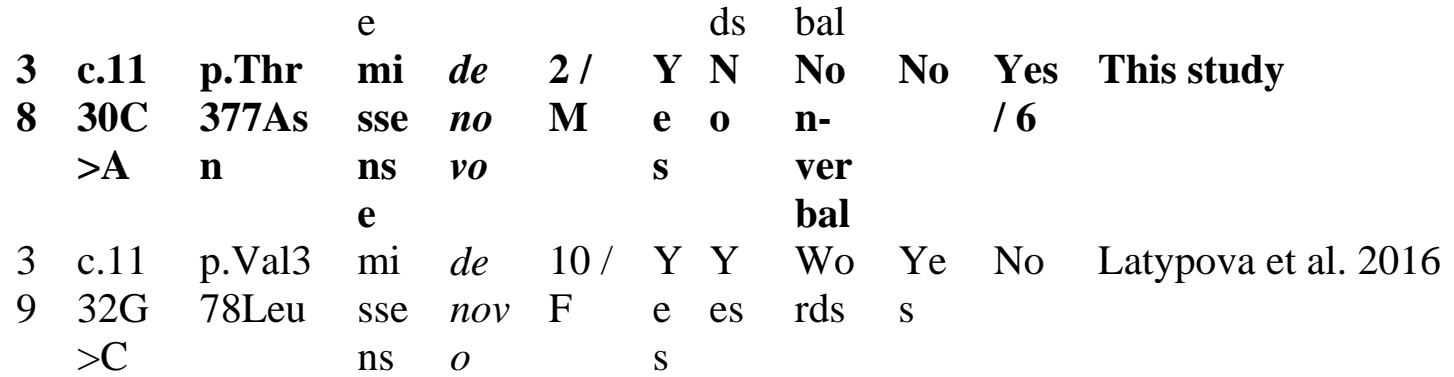

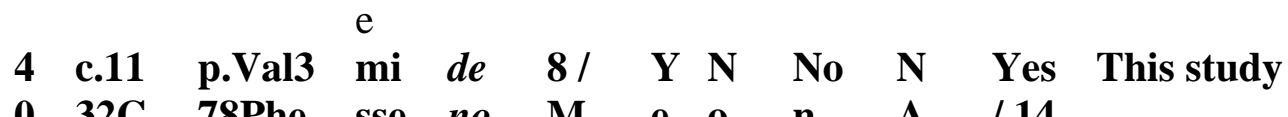

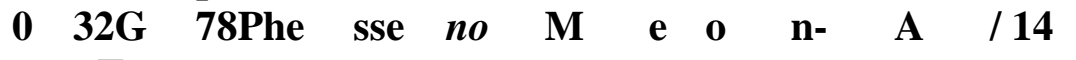
$\begin{array}{lllll} & \text { ns } & \text { vo } & \mathrm{s} & \text { ver }\end{array}$

4 c.11 p.Val3 $\begin{aligned} & \mathbf{m i} \\ & \mathrm{mi}\end{aligned}$ de $3 / \mathrm{Y} \quad \mathrm{N} \quad \begin{aligned} & \text { bal } \\ & \text { No }\end{aligned} \mathrm{N} \quad$ Yes Soden et al. 2014,

1 33T 78Ala sse nov F e o n- A / 13 Thiffault et al. 2015, $>$ C ns $o$ S $\quad$ ver $\quad$ De Kovel et al. 2017

4 c.11 p.Gly3 $\begin{aligned} & \mathrm{mi} \\ & \text { de }\end{aligned}$

2 35G 79Arg sse nov $\mathrm{M}$ e es n- $\mathrm{s} \quad$ / 8 2014 (individual 2), $>\mathrm{A}$ ns $o$ S $\quad$ ver $\quad$ Srivastava et al. e bal 2014, De Kovel et al. 2017 (patient 11)

4 c.11 p.Gly3 mi de $2 / \quad$ Y $\quad \mathrm{N}$ NA $\mathrm{N} \quad$ Yes Miao et al. 2017

$\begin{array}{llllllllll}3 & 36 \mathrm{G} & 79 \mathrm{Val} & \text { sse nov } & \mathrm{ND} & \mathrm{e} & \mathrm{A} & & \mathrm{A} & / 24\end{array}$
e
$\begin{array}{llllllllllll}4 & \text { c.11 } & \text { p.Tyr } & \text { mi } & \text { de } & 5,5 & \text { Y } & \text { Y } & \text { Wo } & \text { No } & \text { Yes } & \text { This study }\end{array}$
4 39A 380Cy sse nov /F e es rds $/ 6$ $>\mathbf{G} \quad \mathbf{S}$ ns $O \quad \mathbf{S}$ 


\begin{tabular}{|c|c|c|c|c|c|c|c|c|c|c|c|}
\hline & & & & & & & & & & & \\
\hline 4 & c.11 & p.Gly3 & $\mathrm{mi}$ & de & $7 /$ & $\mathrm{Y}$ & $\mathrm{N}$ & NA & $\mathrm{N}$ & Yes & Allen et al. 2016 \\
\hline 5 & $41 G$ & 81Arg & sse & nov & M & $\mathrm{e}$ & 0 & & A & $/ 3$ & (patient 7), De Kovel \\
\hline & $>\mathrm{A}$ & & $\begin{array}{l}\text { ns } \\
\text { e }\end{array}$ & $o$ & & $\mathrm{~s}$ & & & & & $\begin{array}{l}\text { et al. } 2017 \text { (patient } \\
\text { 10) }\end{array}$ \\
\hline 4 & c.11 & p.Asp & mi & de & $6 /$ & $\mathbf{Y}$ & $\mathbf{Y}$ & No & No & Yes & This study \\
\hline 6 & 44G & 382As & sse & no & $\mathbf{F}$ & $\mathbf{e}$ & es & n- & & / 8 & \\
\hline & $>\mathbf{A}$ & n & $\begin{array}{l}\text { ns } \\
\text { e }\end{array}$ & vo & & $\mathbf{s}$ & & $\begin{array}{l}\text { ver } \\
\text { bal }\end{array}$ & & & \\
\hline 4 & c.11 & p.Pro3 & $\mathrm{mi}$ & de & $17 /$ & $\mathrm{Y}$ & $\mathrm{W}$ & No & $\mathrm{Ye}$ & Yes & De Kovel et al. 2017 \\
\hline 7 & $53 \mathrm{C}$ & 85Thr & sse & nov & M & $\mathrm{e}$ & ith & $n-$ & $\mathrm{s}$ & / 13 & (patient 9) \\
\hline & $>\mathrm{A}$ & & $\begin{array}{l}\text { ns } \\
\text { e }\end{array}$ & $o$ & & $\mathrm{~s}$ & $\begin{array}{l}\text { ai } \\
\text { ds }\end{array}$ & $\begin{array}{l}\text { ver } \\
\text { bal }\end{array}$ & & & \\
\hline 4 & c.11 & p.Lys3 & $\mathrm{mi}$ & de & NA & $\mathrm{N}$ & $\mathrm{N}$ & NA & $\mathrm{N}$ & NA & Fitzgerald et al. \\
\hline 8 & $73 \mathrm{~A}$ & 91Asn & sse & nov & & $\mathrm{A}$ & A & & A & & 2015, De Kovel et al. \\
\hline & $>\mathrm{C}$ & & $\begin{array}{l}\text { ns } \\
\mathrm{e}\end{array}$ & $o$ & & & & & & & 2017 (patient 8) \\
\hline 4 & c.11 & p.Gly3 & mi & de & $9 /$ & $\mathbf{Y}$ & $\mathbf{Y}$ & No & Ye & Yes & This study \\
\hline 9 & $80 G$ & 94Arg & sse & no & $\mathbf{F}$ & $\mathbf{e}$ & es & n- & $\mathbf{s}$ & / & \\
\hline & $>\mathbf{A}$ & & $\begin{array}{l}\text { ns } \\
\mathbf{e}\end{array}$ & vo & & $\mathbf{s}$ & & $\begin{array}{l}\text { ver } \\
\text { bal }\end{array}$ & & 3,5 & \\
\hline 5 & c.11 & p.Gly3 & mi & de & 9.5 & $\mathbf{Y}$ & $\mathbf{Y}$ & No & Ye & Yes & This study \\
\hline $\mathbf{0}$ & 83G & 95Arg & sse & no & $/ \mathbf{F}$ & $\mathbf{e}$ & es & n- & $\mathbf{s}$ & $/ 12$ & \\
\hline & $>\mathbf{A}$ & & $\begin{array}{l}\text { ns } \\
\mathbf{e}\end{array}$ & vo & & $\mathbf{s}$ & & $\begin{array}{l}\text { ver } \\
\text { bal }\end{array}$ & & & \\
\hline 5 & c.11 & p.Gly3 & $\mathrm{mi}$ & NA & $14 /$ & $\mathrm{Y}$ & $\mathrm{N}$ & No & $\mathrm{Ye}$ & Yes & This study \\
\hline 1 & $83 G$ & 95Arg & sse & & M & $\mathrm{e}$ & 0 & $\mathrm{n}-$ & s & / 8 & \\
\hline & $>\mathrm{A}$ & & $\begin{array}{l}\text { ns } \\
\mathrm{e}\end{array}$ & & & $\mathrm{s}$ & & $\begin{array}{l}\text { ver } \\
\text { bal }\end{array}$ & & & \\
\hline 5 & c.11 & p.Cys3 & $\mathrm{mi}$ & de & $22 /$ & $\mathrm{Y}$ & $\mathrm{N}$ & NA & $\mathrm{N}$ & Yes & De Kovel et al. 2017 \\
\hline 2 & $90 G$ & 97Phe & sse & nov & M & $\mathrm{e}$ & A & & A & $/ 10$ & (patient 7) \\
\hline & $>\mathrm{T}$ & & $\begin{array}{l}\text { ns } \\
\mathrm{e}\end{array}$ & $O$ & & S & & & & & \\
\hline 5 & c.12 & p.Gly4 & $\mathrm{mi}$ & de & $4 /$ & $\mathrm{Y}$ & $\mathrm{N}$ & No & $\mathrm{N}$ & Yes & Saitsu et al. 2015 \\
\hline 3 & $01 G$ & 01Arg & sse & nov & M & e & 0 & $\mathrm{n}-$ & A & / 17 & (patient 1), De Kovel \\
\hline & $>\mathrm{A}$ & & $\begin{array}{l}\text { ns } \\
\mathrm{e}\end{array}$ & $O$ & & $\mathrm{~s}$ & & $\begin{array}{l}\text { ver } \\
\text { bal }\end{array}$ & & & et al. 2017 (patient 6) \\
\hline 5 & c.12 & p.Gly4 & $\mathrm{mi}$ & de & $9 /$ & $\mathrm{Y}$ & $\mathrm{N}$ & No & $\mathrm{N}$ & Yes & This study \\
\hline 4 & $01 G$ & 01Arg & sse & nov & M & $\mathrm{e}$ & 0 & $n-$ & $\mathrm{A}$ & $/ 8$ & \\
\hline & $>\mathrm{A}$ & & $\begin{array}{l}\text { ns } \\
\mathrm{e}\end{array}$ & $O$ & & $\mathrm{~s}$ & & $\begin{array}{l}\text { ver } \\
\text { bal }\end{array}$ & & & \\
\hline 5 & c.12 & p.Ile4 & mi & de & $8 /$ & $\mathbf{Y}$ & $\mathbf{Y}$ & Sen & Ye & No & This study \\
\hline 5 & $26 \mathrm{~T}$ & 09Thr & sse & no & $\mathbf{M}$ & e & es & ten & s & & \\
\hline & $>\mathrm{C}$ & & $\begin{array}{l}\text { ns } \\
\mathbf{e}\end{array}$ & vo & & $\mathbf{s}$ & & ces & & & \\
\hline 5 & c.12 & p.Phe4 & $\mathrm{mi}$ & de & $15 /$ & $\mathrm{Y}$ & $\mathrm{N}$ & NA & $\mathrm{Ye}$ & Yes & Allen et al. 2016 \\
\hline 6 & $48 \mathrm{C}$ & 16Leu & sse & nov & $\mathrm{F}$ & $\mathrm{e}$ & A & & s & $/ 14$ & (patient 8), De Kovel \\
\hline & $>\mathrm{G}$ & & ns & $O$ & & $\mathrm{~s}$ & & & & & et al. 2017 (patient 5) \\
\hline
\end{tabular}

This article is protected by copyright. All rights reserved. 


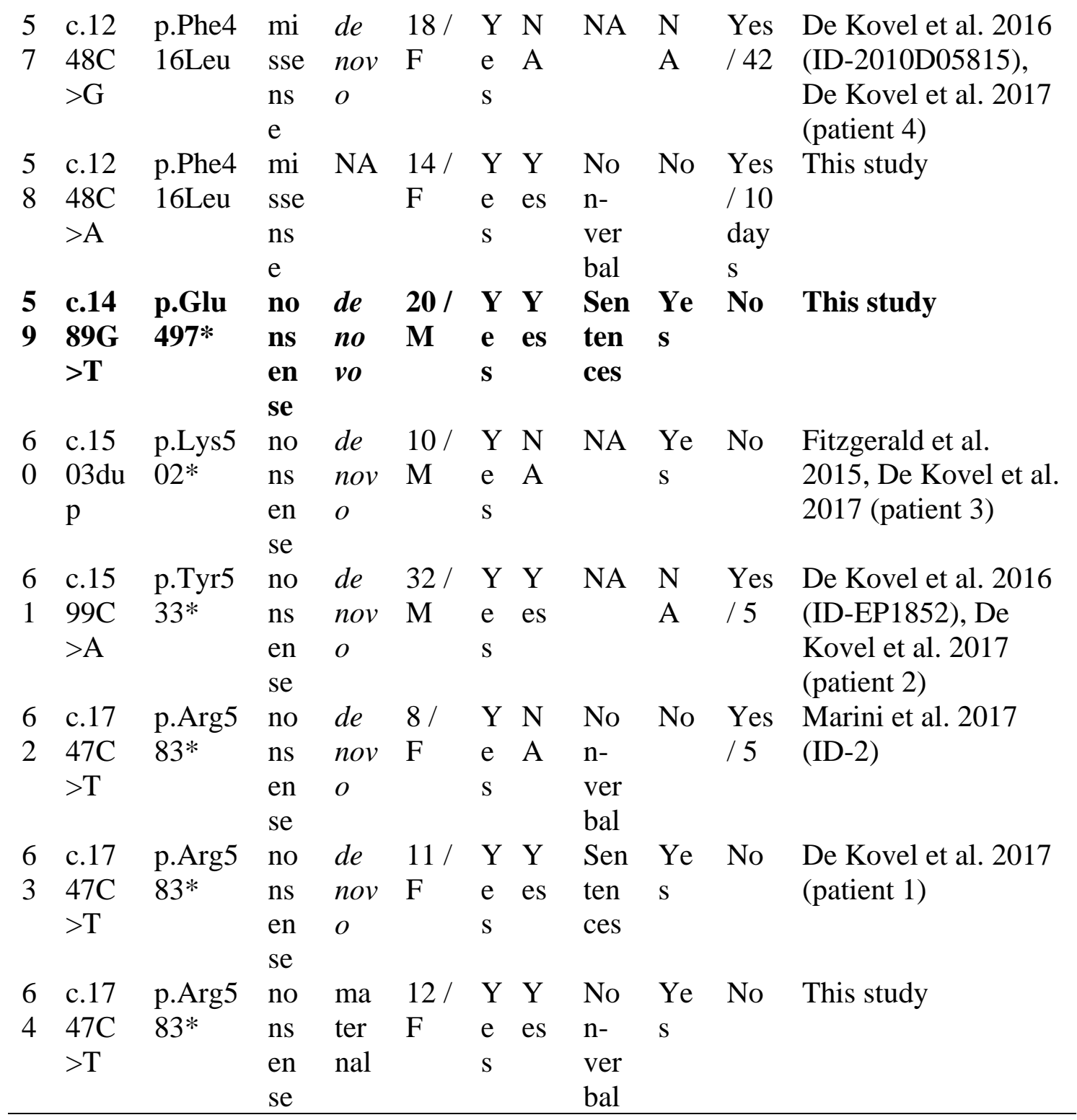

Numbering is according to the cDNA sequence (RefSeq NM_004975.2).

Novel mutations are indicated in bold.

y: years, m: months, DD: developmental delay, sz: seizures, NA: Not available † This patient also carries a de novo variant in GABRA5 (NM_000810:c.902C > T, p.Thr301Met). 


\section{University Library}

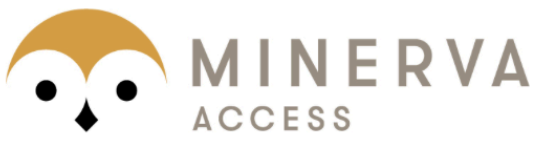

A gateway to Melbourne's research publications

Minerva Access is the Institutional Repository of The University of Melbourne

Author/s:

Bar, C;Barcia, G;Jennesson, M;Le Guyader, G;Schneider, A;Mignot, C;Lesca, G;Breuillard, D;Montomoli, M;Keren, B;Doummar, D;de Villemeur, TB;Afenjar, A;Marey, I;Gerard, M;Isnard, H;Poisson, A;Dupont, S;Berquin, P;Meyer, P;Genevieve, D;De Saint Martin, A;El Chehadeh, S;Chelly, J;Guet, A;Scalais, E;Dorison, N;Myers, CT;Mefford, HC;Howell, KB;Marini, C;Freeman, JL;Nica, A;Terrone, G;Sekhara, T;Lebre, A-S;Odent, S;Sadleir, LG;Munnich, A;Guerrini, R;Scheffer, IE;Kabashi, E;Nabbout, R

Title:

Expanding the genetic and phenotypic relevance of KCNB1 variants in developmental and epileptic encephalopathies: 27 new patients and overview of the literature

Date:

2020-01-01

\section{Citation:}

Bar, C., Barcia, G., Jennesson, M., Le Guyader, G., Schneider, A., Mignot, C., Lesca, G., Breuillard, D., Montomoli, M., Keren, B., Doummar, D., de Villemeur, T. B., Afenjar, A., Marey, I., Gerard, M., Isnard, H., Poisson, A., Dupont, S., Berquin, P. ,... Nabbout, R. (2020). Expanding the genetic and phenotypic relevance of KCNB1 variants in developmental and epileptic encephalopathies: 27 new patients and overview of the literature. HUMAN MUTATION, 41 (1), pp.69-80. https://doi.org/10.1002/humu.23915.

Persistent Link:

http://hdl.handle.net/11343/286479 